\title{
Evaluation of the effects of sugarcane molasses as a carbon source for Ankistrodesmus gracilis and Haematococcus pluvialis (Chlorophyceae)
}

\author{
L. H. Sipaúba-Tavares ${ }^{a *}$ (D), M. G. Tedesque (D) and B. Scardoeli-Truzzia (D) \\ ${ }^{a}$ Centro de Aquicultura, Universidade Estadual Paulista — UNESP, Via de Acesso Prof. Paulo Donato Castellane, s/n, \\ CEP 14884-900, Jaboticabal, SP, Brasil \\ *e-mail: lucia.sipauba@unesp.br
}

Received: November 23, 2018 - Accepted: April 23, 2019 - Distributed: August 31, 2020

(With 3 figures)

\begin{abstract}
Two species of Chlorophyceae, Ankistrodesmus gracilis and Haemotococcus pluvialis, were used to compare and evaluate the effect of sugarcane molasses as a carbon source. Highest cell density in the two microalgae culture media was obtained in commercial culture media $\left(\mathrm{CHU}_{12}\right.$ and WC). During exponential growth (day 1 to day 10), high cell density in $H$. pluvialis was detected for E. crassipes culture medium ranging between $0.4 \times 10^{5} \mathrm{cells}^{\mathrm{mL}} \mathrm{L}^{-1} \mathrm{and}$ $1.7 \times 10^{5}$ cells $\mathrm{mL}^{-1}$. Culture media were fundamental for growth under mixotrophic cultivation. Sugarcane molasses showed different results for the two microalgae with regard to growth performance, lipid and protein levels. Rates were high for $H$. pluvialis except lipid at the end of the experiment. In fact, A. gracilis presented almost double the lipid levels. Sugarcane molasses may be an alternative carbon source in laboratory conditions.
\end{abstract}

Keywords: alternative culture media, mixotrophic cultivation, growth, biochemical composition.

\section{Avaliação do efeito do melaço de cana-de-açúcar como fonte de carbono para Ankistrodesmus gracilis e Haematococcus pluvialis (Chlorophyceae)}

\begin{abstract}
Resumo
Duas espécies de Chlorophyceae, Ankistrodesmus gracilis e Haemotococcus pluvialis foram utilizadas para comparar o efeito do melaço de cana-de-açúcar como fonte de carbono. Nos dois meios de cultura de microalgas, a maior densidade celular foi obtida em meio de cultura comercial $\left(\mathrm{CHU}_{12}\right.$ e WC). Durante o crescimento exponencial $\left(1^{\circ}\right.$ ao $10^{\circ}$ dia),

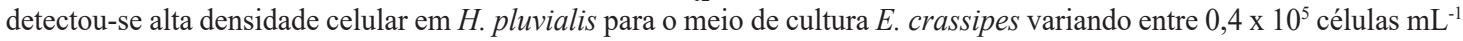
e $1,7 \times 10^{5}$ células $\mathrm{mL}^{-1}$. Os meios de cultura foram fundamentais para o crescimento em cultivo mixotrófico. $\mathrm{O}$ melaço de cana-de-açúcar apresentou resultados diferentes para as duas microalgas em relação ao crescimento, aos teores de proteína e lipídio foram mais elevados para o cultivo de H. pluvialis, exceto lipídio no final do experimento onde A. gracilis apresentou quase o dobro dos níveis de lipídio. O melaço de cana de açúcar pode ser uma fonte alternativa de carbono em condições de laboratório.
\end{abstract}

Palavras-chave: meios de cultura alternativos, cultivo mixotrófico, crescimento, composição bioquímica.

\section{Introduction}

The optimization and the reduction of production costs are crucial for the implementation of a successful algal crop. Alternative sources, such as inorganic fertilizers, aquatic plants and sugarcane molasses, are being used to reduce production costs and increase algal biomass. Microalgae may be cultured for several purposes, such as proteins, carbohydrate, lipids, micronutrients, food additives, cosmetics and diet supplements for animal feeding since they are a source of essential amino-acids (Madeira et al., 2017). The main applications of microalgae in aquaculture are directly associated with nutrition of various species of farmed aquatic animals, increasing the nutritional value of fish (Sathazivam et al., 2018). However, the cultivation of microalgae requires high costs that often impair the production of high biomass microalgae to be used on the market.

In the case of the economic biomass cultivation of microalgae, it is necessary to explore the possibility of using a low-cost carbon source such as sugarcane molasses. Organic carbon sources such as glucose or acetate are usually expensive. However, a cheap industrial by-product, such as sugarcane molasses, could be used as a low-cost medium supplement. Molasses consist of 50\% total sugars, predominantly sucrose, since they contain significant amounts of reducing sugars such as glucose, fructose and other carbohydrates (Piasecka et al., 2017). 
Glucose provides more energy contents than any other carbon source, approximately $2.8 \mathrm{KJ} \mathrm{mol}^{-1}$, when compared to $0.8 \mathrm{KJ} \mathrm{mol}^{-1}$ for acetate (Cheah et al., 2018).

Compared to phototrophic growth, heterotrophic cultivation has gained special attention due to high cell density and biomass production rate. Algal cultivation may be performed with other organic carbon sources, such as acetate organic acid and light in a process known as mixotrophy, where the availability of organic carbon for inorganic carbon assimilation is fixed by photosynthesis (Wang et. al., 2017). Cell growth in mixotrophic conditions is not strictly dependent on photosynthesis and enhances microalgae growth with various nitrogen source (Li et al., 2019).

Heterotrophic and mixotrophic cultivation is a feasible alternative strategy to avoid problems in microalgae growth, such as biomass concentration and growth rate which may be greatly increased. Further, the accumulation of certain specific products may be remarkably enhanced (Wang et al., 2018). Sugarcane molasses is a suitable carbon source for heterotrophic culture of a number of microalgae species (Gaurav et al., 2016). Exogenous carbon source is a necessary element in the heterotrophic culture. However, mixotrophic cultivation is the best approach to produce enhanced biomass and higher total lipid content because it uses phototrophic and heterotrophic modes of cultivation (Mondal et al., 2017). Up to the present, sugarcane molasses have been reported as a carbon source for the production of Botryococcus braunii, Chlorella vulgaris, C. sorokiana, C. zofingiensis, Haemotococcus pluvialis, Scenedesmus obliquus and Spirulina platensis biomass for astaxanthin or biodiesel production (Piasecka et al., 2017).

The important aspect of technological development and improvement of microalgae growth is the prediction of the process performance and the optimization of culture-operating condition (Gaurav et al., 2016). To date, no study has yet been performed on growth of Ankistrodesmus gracilis using sugarcane molasses as a carbon source in commercial $\left(\mathrm{CHU}_{12}\right)$ and in alternative media (inorganic fertilizer and macrophytes - Eichhornia crassipes). However, in the case of $H$. pluvialis cells are capable of employing exogenous carbon sources, although the use of NPK and macrophyte culture media is a novelty. Ankistrodesmus gracilis and H. pluvialis are green freshwater microalgae, proven as a good resource of protein for fish pigmentation and biodiesel production. Current analysis evaluates whether sugarcane molasses may be employed as an external source of carbon to be used by $A$. gracilis and $H$. pluvialis.

\section{Methods}

\subsection{Microalgae culture and laboratory conditions}

Microalgae Ankistrodesmus gracilis $(005 \mathrm{CH})$ and Haematococcus pluvialis (CMEA $227 \mathrm{C} 1$ ) were used to observe the effects on growth by different culture media under mixotrophic condition. Algae were batch-cultured at $22 \pm 2{ }^{\circ} \mathrm{C}$ and exposed to light at $60 \mu \mathrm{mol} \mathrm{m} \mathrm{m}^{-2} \mathrm{~s}^{-1}$ for A. gracilis and $40 \mu \mathrm{mol} \mathrm{m} \mathrm{m}^{-2} \mathrm{~s}^{-1}$ for H. pluvialis, in a $24-\mathrm{h}$ light cycle. Four culture media were used, namely, two commercial media $\mathrm{CHU}_{12}$ (Chu, 1942) and WC (Guillard and Lorenzen, 1972) and two alternative media, one with inorganic fertilizer NPK (20-5-20) for $A$. gracilis (Sipaúba-Tavares and Rocha, 1993) and NPK (10-10-10) for H. pluvialis (Scardoelli-Truzzi and Sipaúba-Tavares, 2017) and a macrophyte culture medium with the aquatic plant Eichhornia crassipes (EC) (Sipaúba-Tavares et al., 2009). The latter consisted of approximately $5 \mathrm{~kg}$ (wet-weight) of the plant, washed gently in tap water to remove detritus and epiphytes. The plant material was initially dried in the sun and subsequently in an oven at $60^{\circ} \mathrm{C}$ for 24 hours. The dried plant material was homogenized in a grinder and boiled in distilled water for one hour. The hot extract was filtered and autoclaved at $120^{\circ} \mathrm{C}$ during 20 minutes. A $70 \mathrm{~mL}$ sample was collected and cooled. It was diluted with distilled water up to $1.4 \mathrm{~L}$, when $2.5 \mathrm{~mL}$ NPK were added. The experiment started at a density of $3 \times 10^{5}$ cells mL ${ }^{-1}$ for $A$. gracilis, and at $0.26 \times 10^{5}{\text { cells } \mathrm{mL}^{-1}}^{-1}$ for $H$. pluvialis, containing commercial, inorganic fertilizer and macrophyte media with continuous air bubbling. Vitamin $\mathrm{B}$ complex was added to the alternatives media at the rate of $0.02 \mathrm{~g} \mathrm{~L}^{-1}(7 \mathrm{mg}$ - B1; $7 \mathrm{mg}$ - B2; $5 \mathrm{mg}$ - B6; $33 \mu \mathrm{g}$ - B12) plus vitamin $\mathrm{H}(0.1 \mathrm{mg})$. Continuous illumination was applied and the alternatives and commercial media were employed to grow the microalgae cultures in $2 \mathrm{~L}$. Cell growth was evaluated in triplicate $(\mathrm{n}=3)$ for 28 days, in all treatments.

\subsection{Composition and concentration of sugarcane molasses}

Sugarcane molasses, $82.62^{\circ} \mathrm{BX}$ and $\mathrm{pH}$ 5.9, were obtained from Brazilian Molasses Ltda (Brazil). Sugarcane molasses contained $20 \%$ water, $8 \%$ fructose, $7 \%$ glucose and metal ions, such as calcium, potassium, sodium, iron, magnesium, copper, and others. Crude molasses were diluted in distilled water and autoclaved at $1 \mathrm{~atm}$, for 30 minutes. The solution was subsequently used in assays for mixotrophic culture. Further, $1.5 \mathrm{~g} \mathrm{~L}^{-1}$ and $0.75 \mathrm{~g} \mathrm{~L}^{-1}$ concentrations of sugarcane molasses were added to the culture media, respectively, for A. gracilis and H. pluvialis.

\subsection{Growth performance}

Cell growth was monitored for 28 days. Triplicate $1 \mathrm{~mL}$ aliquots were removed daily from the microalgae culture and 2 x $1 \mathrm{~mL}$ sub-samples were used for cell quantification by a Neubauer haemocytometer. Growth rate $(\mathrm{k})$ was calculated by the formula $\mathrm{k}=\left(3.322 / \mathrm{t}_{2}-\mathrm{t}_{1} \times \log \mathrm{N}_{2} / \mathrm{N}_{1}\right)$ ( $\mathrm{t}=$ time; $\mathrm{N}=$ number of cells; subscripts denote rates at different times) (Guillard, 1973). Doubling time (cell division time or generation time) was calculated from results obtained from growth rate, by formula $\mathrm{Td}=1 \mathrm{k}^{-1}$ $\left(\mathrm{Td}=\right.$ duplication time, $1 \mathrm{k}^{-1}=$ days per division) (Guillard, 1973). Total length of 50 specimens was determined by microscope Leica DFC 295 with image analysis system LAS core (LAS V3.8), and 400x micrometric objective. Cell volume was calculated by mean cell size with the use of the most appropriate geometric form, or rather 
two coupled cone formula in the case of $A$. gracilis and a sphere formula in the case of $H$. pluvialis (Hillebrand et al., 1999). Total organic carbon (TOC) was calculated by $\mathrm{C}=0.1204 \mathrm{~V}^{1.051}\left(\mathrm{C}=\right.$ carbon content in pg cell ${ }^{-1} ; \mathrm{V}=$ cell volume) by regression following Rocha and Duncan (1985). Microalgae biomass was harvested, centrifuged and lyophilized for the analysis of proteins and lipids (AOAC, 1990). Protein and lipids were analyzed on the first (day 1) and last (day 28) day of the experiment. Chlorophyll- $a$ was extracted with alcohol $90 \%$ and quantified at $663 \mathrm{~nm}$ and 750nm (Nusch, 1980).

\subsection{Parameters of culture media}

Physical and chemical parameters of culture media were performed weekly. Dissolved oxygen (DO), $\mathrm{pH}$ and conductivity of culture media were measured with YSI 556 MPS multi-sensor. Total phosphorous (TP) and total inorganic nitrogen (TIN) were quantified by spectrophotometry, following Golterman et al. (1978) and Koroleff (1976). Analyses were performed immediately after sampling or samples were duly stored under refrigeration.

\subsection{Data analysis}

All data underwent one-way analysis of variance (ANOVA) with Statistica 8.0 package to test the effects of the culture media for each microalga (Statsoft Inc., 2007). Tukey's test was applied when differences between culture media occurred. Differences were considered significant at $\mathrm{p}<0.05$. All experiments were carried out in triplicate.

\section{Results}

Cell density of Ankistrodesmus gracilis in mixotrophic cultivation was higher than that of Haematococcus pluvialis. In the case of the two microalgae culture media, the highest cell density was obtained in commercial culture media $\left(\mathrm{CHU}_{12}\right.$ and WC). Cell density of $A$. gracilis was different in NPK and in macrophyte (EC) culture media. All cells died on the $18^{\text {th }}$ day of the experiment in the NPK medium (Figure 1). During exponential growth, that is, the first
10 days of cultivation, high cell density of Haematococcus pluvialis was observed in EC culture medium, ranging between $0.4 \times 10^{5}$ cells $\mathrm{mL}^{-1}$ and $1.7 \times 10^{5}$ cells $\mathrm{mL}^{-1}$, whilst in WC and NPK culture media ranged between $0.5 \times 10^{5}$ cells $\mathrm{mL}^{-1}$ and $1.3 \times 10^{5}$ cells $\mathrm{mL}^{-1}$ and between $0.3 \times 10^{5}$ cells $\mathrm{mL}^{-1}$ and $1 \times 10^{5}$ cells $\mathrm{mL}^{-1}$, respectively (Figure 1). After the $12^{\text {th }}$ day, the highest cell density of H. pluvialis was obtained in WC medium until the end of the experiment $\left(28^{\text {th }}\right.$ day). However, after the $17^{\text {th }}$ day, cell density in NPK culture medium was higher $(\mathrm{p}<0.05)$ than in EC culture medium (Figure 1).

Parameters for Ankistrodesmus gracilis growth were higher $(\mathrm{p}<0.05)$ in $\mathrm{CHU}_{12}$ under mixotrophic cultivation except dry biomass $\left(215 \pm 90\right.$ pg cell $\left.{ }^{-1}\right)$, which was higher in NPK culture medium, and chlorophyll- $a$ with no difference $(\mathrm{p}>0.05)$ between culture media. In case of $H$. pluvialis under mixotrophic cultivation, several parameters, such as total length, cell volume, TOC and chlorophyll- $a$, were similar $(\mathrm{p}>0.05)$ between the media. Highest growth parameters were obtained in WC culture medium with regard to cell density that directly influenced doubling time and growth rate. Dry biomass in EC culture medium was high $(\mathrm{p}<0.05)$, with 4,682 $\pm 1,495 \mathrm{pg} \mathrm{cell}^{-1}$. In fact, it was almost twice as much as the other culture medium (Table 1).

Lipid and protein in A. gracilis cultivation increased at the end of the experiment, except in the NPK culture medium for lipid. Lipid and protein levels in H. pluvialis decreased at the end of the experiment. Higher final protein content in $H$. pluvialis was observed in NPK medium with $39.6 \%$ dry biomass, when compared to WC $(32.3 \%)$ and EC $(27.1 \%)$ culture media. Lipid content was low, below $1.3 \%$, at the end of the experiment. As a rule, WC and NPK had similar lipid contents (Figure 2).

Total inorganic nitrogen (TIN) and TP in the two microalgae were high, above $1 \mathrm{~g} \mathrm{~L}^{-1}$ (EC) and $0.5 \mathrm{~g} \mathrm{~L}^{-1}$ $\left(\mathrm{CHU}_{12}\right)$ for $A$. gracilis, and $0.4 \mathrm{~g} \mathrm{~L}^{-1}(\mathrm{EC})$ and $0.1 \mathrm{~g} \mathrm{~L}^{-1}$ (WC) for H. pluvialis, respectively. However, the highest concentrations of these compounds were obtained in NPK
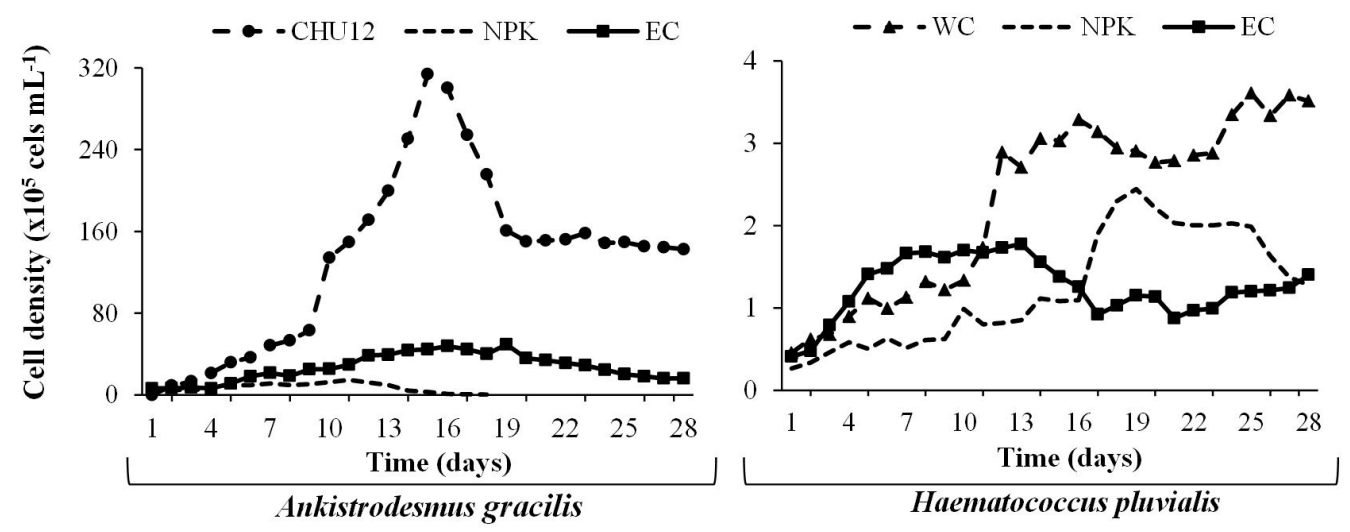

Figure 1. Daily concentration of Ankistrodesmus gracilis and Haematococcus pluvialis in different culture media $\left(\mathrm{CHU}_{12}, \mathrm{WC}_{\text {, }}\right.$ NPK and macrophyte, Eichhornia crassipes-EC) under mixotrophic cultivation. 
Table 1. Parameters of growth and water culture media of Ankistrodesmus gracilis and Haematococcus pluvialis cultured in commercial media $\left(\mathrm{CHU}_{12}\right.$ and WC) and alternatives media (NPK and macrophyte-Eichhornia crassipes-EC), under mixotrophic culture.

\begin{tabular}{|c|c|c|c|c|c|c|}
\hline \multirow{2}{*}{ Parameters } & \multicolumn{3}{|c|}{ Ankistrodesmus gracilis } & \multicolumn{3}{|c|}{ Haematococcus pluvialis } \\
\hline & $\mathrm{CHU}_{12}$ & NPK & EC & WC & NPK & $\mathbf{E C}$ \\
\hline \multicolumn{7}{|l|}{ Culture Media } \\
\hline $\mathrm{TIN}\left(\mathrm{g} \mathrm{L}^{-1}\right)$ & $2.3 \pm 1.1^{\mathrm{b}}$ & $4.4 \pm 0.7^{\mathrm{a}}$ & $1.4 \pm 0.2^{\mathrm{b}}$ & $2.56 \pm 1.6^{\mathrm{b}}$ & $3.1 \pm 0.1^{\mathrm{a}}$ & $0.77 \pm 0.2^{c}$ \\
\hline $\mathrm{TP}\left(\mathrm{g} \mathrm{L}^{-1}\right)$ & $1.0 \pm 0.3^{\mathrm{b}}$ & $1.7 \pm 0.1^{\mathrm{a}}$ & $0.9 \pm 0.1^{\mathrm{b}}$ & $0.85 \pm 0.6^{\mathrm{b}}$ & $2.95 \pm 0.7^{\mathrm{a}}$ & $0.37 \pm 0.04^{\mathrm{b}}$ \\
\hline $\mathrm{DO}\left(\mathrm{mg} \mathrm{L}^{-1}\right)$ & $6.9 \pm 0.5^{\mathrm{a}}$ & $6.2 \pm 0.5^{\mathrm{a}}$ & $6.5 \pm 0.4^{\mathrm{a}}$ & $7.6 \pm 0.5^{\mathrm{a}}$ & $7.2 \pm 0.1^{\mathrm{a}}$ & $7.2 \pm 0.1^{\mathrm{a}}$ \\
\hline $\mathrm{pH}$ & $9.3 \pm 2.4^{\mathrm{a}}$ & $10.3 \pm 3.1^{\mathrm{a}}$ & $10.4 \pm 1.2^{\mathrm{a}}$ & $7.6 \pm 0.8^{\mathrm{b}}$ & $7.4 \pm 0.2^{\mathrm{b}}$ & $8.5 \pm 0.1^{\mathrm{a}}$ \\
\hline Conductivity $\left(\mu \mathrm{S} \mathrm{cm}^{-1}\right)$ & $882 \pm 78^{b}$ & $1,542 \pm 247^{a}$ & $680 \pm 66^{\mathrm{b}}$ & $706 \pm 108^{\mathrm{a}}$ & $844 \pm 90^{\mathrm{a}}$ & $762 \pm 32^{\mathrm{a}}$ \\
\hline \multicolumn{7}{|l|}{ Microalgae } \\
\hline Max. density $\left(\mathrm{x} 10^{5} \mathrm{~mL}^{-1}\right)$ & 300.33 & 12.12 & 49.35 & 3.6 & 2.44 & 1.77 \\
\hline Mean density $\left(\mathrm{x} 10^{5} \mathrm{~mL}^{-1}\right)$ & $135 \pm 86$ & $7.3 \pm 4.4$ & $27 \pm 14$ & $2.28 \pm 1.1$ & $1.23 \pm 0.6$ & $1.24 \pm 0.36$ \\
\hline Growth rate $(\mathrm{k})$ & 0.89 & 0.08 & 0.16 & 0.24 & 0.17 & 0.17 \\
\hline Doubling time (days) & 2.56 & 11.96 & 6.09 & 4.11 & 5.63 & 5.66 \\
\hline Total lenght $(\mu \mathrm{m})$ & $11 \pm 1.5^{\mathrm{a}}$ & $7.9 \pm 0.2^{\mathrm{b}}$ & $8.3 \pm 0.3^{\mathrm{b}}$ & $25.3 \pm 0.6^{\mathrm{a}}$ & $25.7 \pm 6.1^{\mathrm{a}}$ & $24.7 \pm 24^{\mathrm{a}}$ \\
\hline Cell volume $\left(\mu \mathrm{m}^{3}\right)$ & $13 \pm 5.7^{\mathrm{a}}$ & $5.9 \pm 1.3^{\mathrm{b}}$ & $5.9 \pm 1.0^{\mathrm{b}}$ & $9,724 \pm 1,245^{\mathrm{a}}$ & $12,044 \pm 9314^{\mathrm{a}}$ & $8,513 \pm 2,829^{a}$ \\
\hline TOC $\left(\mathrm{pg}\right.$ cell $\left.^{-1}\right)$ & $1.8 \pm 0.8^{\mathrm{a}}$ & $0.8 \pm 0.2^{\mathrm{b}}$ & $0.8 \pm 0.1^{\mathrm{b}}$ & $1,892 \pm 266^{\mathrm{a}}$ & $2,394 \pm 1,723^{\mathrm{a}}$ & $1,642 \pm 576^{\mathrm{a}}$ \\
\hline Dry biomass (pg cell ${ }^{-1}$ ) & $50 \pm 49^{b}$ & $215 \pm 90^{\mathrm{a}}$ & $156 \pm 121^{\mathrm{ab}}$ & $2,809 \pm 822^{b}$ & $2,713 \pm 987^{\mathrm{b}}$ & $4,682 \pm 1,495^{\mathrm{a}}$ \\
\hline Chlorophyll- $a\left(\mathrm{~g} \mathrm{~L}^{-1}\right)$ & $135 \pm 47^{\mathrm{a}}$ & $94 \pm 50^{\mathrm{a}}$ & $84 \pm 44^{\mathrm{a}}$ & $614 \pm 183^{\mathrm{a}}$ & $901 \pm 674^{\mathrm{a}}$ & $429 \pm 251^{\mathrm{a}}$ \\
\hline
\end{tabular}

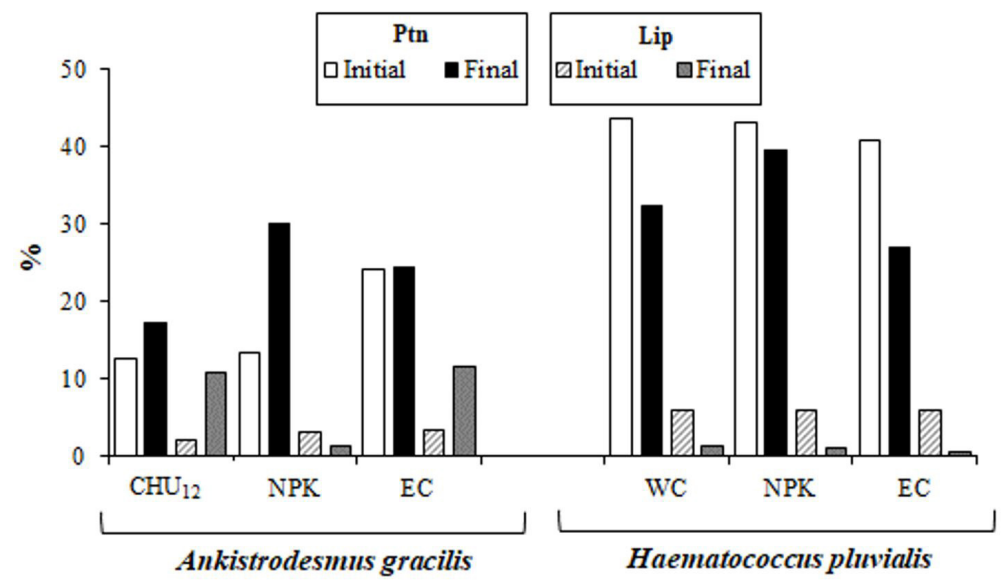

Figure 2. Initial and final variations of proteins (Ptn) and lipids (Lip) (\% dry biomass) content in different culture media $\left(\mathrm{CHU}_{12}, \mathrm{WC}, \mathrm{NPK}\right.$ and macrophyte, Eichhornia crassipes-EC) of Ankistrodesmus gracilis and Haematococcus pluvialis, under mixotrophic cultivation.

medium for the two microalgae. In general, the compounds were higher in A. gracilis culture medium, except for TIN in $\mathrm{WC}\left(2.56 \pm 0.2 \mathrm{~g} \mathrm{~L}^{-1}\right)$ and for TP in NPK $\left(2.95 \pm 0.7 \mathrm{~g} \mathrm{~L}^{-1}\right)$ culture medium, which was higher in $H$. pluvialis culture (Table 1).High TIN and TP concentrations for A. gracilis culture were due to the non-uptake of these compounds during the experimental period, except in $\mathrm{CHU}_{12}$ culture medium with absorption at $2.8 \mathrm{~g} \mathrm{~L}^{-1}$. However, the uptake of these compounds was reported in the case of $H$. pluvialis for all culture media, or rather, TIN absorption amounted to $0.3 \mathrm{~g} \mathrm{~L}^{-1}, 0.4 \mathrm{~g} \mathrm{~L}^{-1}$ and $0.3 \mathrm{~g} \mathrm{~L}^{-1}$ for WC, NPK and EC culture media, respectively. Total phosphorus absorption amounts were higher, or rather, $1.2 \mathrm{~g} \mathrm{~L}^{-1}, 1.6 \mathrm{~g} \mathrm{~L}^{-1}$ and $0.1 \mathrm{~g} \mathrm{~L}^{-1}$, for WC, NPK and EC culture media, respectively (Figure 3).

Constant air bubbling kept DO $(\mathrm{p}>0.05)$ above $6.1 \mathrm{mg} \mathrm{L}^{-1}$ in $A$. gracilis culture and $7.1 \mathrm{mg} \mathrm{L}^{-1}$ in H. pluvialis culture. Conductivity was higher $(\mathrm{p}<0.05)$ in NPK culture medium for A. gracilis, and the same ( $\mathrm{p}>0.05$ ) when culture media for $H$. pluvialis were compared. The two microalgae showed higher conductivity, above $614 \mu \mathrm{S} \mathrm{cm} \mathrm{cm}^{-1}$ (EC - A. gracilis), reaching about $1,773 \mu \mathrm{S} \mathrm{cm}^{-1}$ (NPK - A. gracilis). Moreover, $\mathrm{pH}$ ranged between 6.9 and $12\left(\mathrm{CHU}_{12}\right)$ for $A$. gracilis and between 6.6 (WC) and 8.6 (EC) for H. pluvialis (Table 1). 


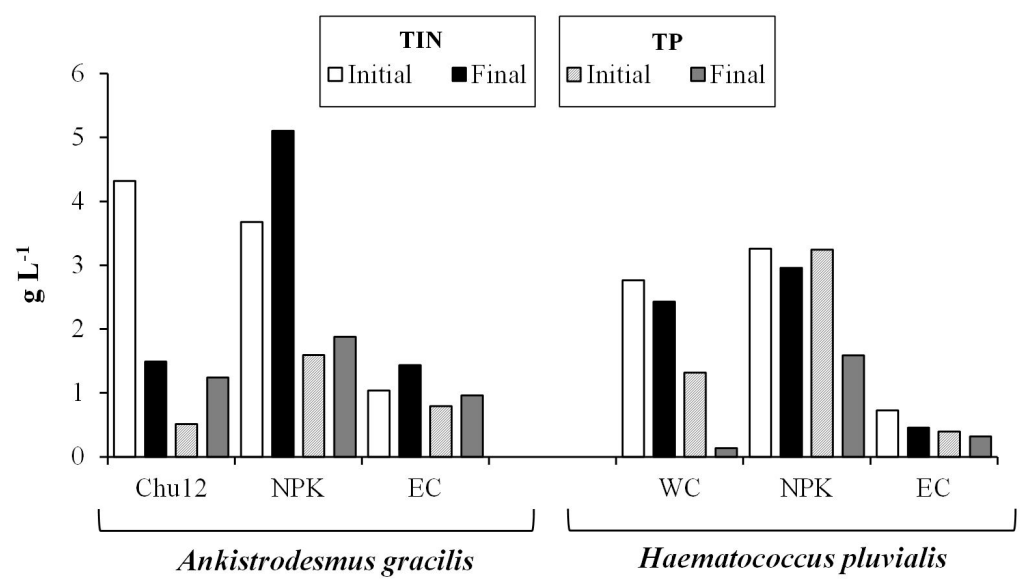

Figure 3. Initial and final concentrations of total inorganic nitrogen (TIN) and total phosphorus (TP) in different culture media (CHU12, WC, NPK and macrophyte, Eichhornia crassipes-EC) of Ankistrodesmus gracilis and Haematococcus pluvialis, under mixotrophic cultivation.

\section{Discussion}

The mixotrophic cultivation of A. gracilis and H. pluvialis with sugarcane molasses as carbon source caused differential growth for each microalga. Different culture media were fundamental for growth performance. In EC alternative culture medium for $H$. pluvialis microalgae, the highest cell density was obtained during growth exponential phase (day 1 to day 10). The biggest biomass production was observed in WC culture medium until the end of the experiment, and it did not exceed $3.6 \times 10^{5}$ cell $\mathrm{mL}^{-1}$. In the case of microalga $A$. gracilis, alternative culture media (NPK and EC) were not as effective for cell density. However, $\mathrm{CHU}_{12}$ commercial culture medium provided the highest algal biomass for $A$. gracilis growth when compared with alternatives media. The metabolic mechanism of raw sugarcane molasses in green algae remain unclear (Wang et al., 2018). Under heterotrophic cultivation most of the algal species under analysis had difficulty in utilizing sucrose either because of their lack of specific sucrose transporter or because they were unable to extracellularly hydrolyze sucrose into monosaccharide. As a result, the growth of microalgae was poor or might not survive (Wang et al., 2018).

The possibility of using low cost agricultural by-products for the growth of microalgae under mixotrophic conditions resulted in growth decrease from the $14^{\text {th }}$ day onwards for $H$. pluvialis and in failure to support growth from $18^{\text {th }}$ day onwards for $A$. gracilis. High cell density for the two microalgae was in commercial culture medium $\left(\mathrm{CHU}_{12}\right.$ and WC). Growth parameters were high for H. pluvialis in mixotrophic cultivation, with chlorophyll- $a$ content between 5 and 9-fold higher than A. gracilis.

Scardoelli-Truzzi and Sipaúba-Tavares (2017) demonstrated that an increase in $H$. pluvialis biomass using $0.75 \mathrm{~g} \mathrm{~L}^{-1}$ of sugarcane molasses concentrations was higher than in phototrophic conditions with regard to cell volume, total length, TOC and dry weight. However, if chlorophyll- $a$ content of $A$. gracilis in autotrophic cultivation (Sipaúba-Tavares et al., 2017) is compared with mixotrophic cultivation, the concentration is 10-fold higher in culture with sugarcane molasses as a carbon source. In mixotrophic cultivation light and organic carbon source fulfil the same role in the growth and cellular composition of microalgae (Piasecka et al., 2017).

Protein and lipid contents in $H$. pluvialis culture decreased at the end of the experiment but increased in A. gracilis, except in NPK medium for lipid. However, total inorganic nitrogen and total phosphorus were higher for the two microalgae in mixotrophic cultivation. Additionally, nitrogen-deficiency in culture media promotes the lipids accumulated in the microalgae biomass. Lipid accumulation starts after nutrients used up for biomass growth. However, sugar cane molasses are a rich source of nitrogen, a very important constituent of protein synthesis and participates in cell division and growth (Piasecka et al., 2017). In current study, when high protein levels were compared to lipid levels, they were affected by high TIN concentrations ranging between $2.4 \mathrm{gL}^{-1}$ (WC $-H$. pluvialis) and $5.1 \mathrm{gL}^{-1}$ (NPK - A. gracilis) for two microalgae in mixotrophic cultivation. High TIN concentration for $A$. gracilis was obtained in NPK medium where protein levels were high. In the case of $H$. pluvialis, high TIN concentration and high protein levels were reported in the NPK and WC. Lipids levels were high at the beginning of the experiment for $H$. pluvialis. They were also high for A. gracilis at the end (28-days) of the experiment. Lipid accumulation depended on several factors such as growth conditions (autotrophic, mixotrophic or heterotrophic), culture age, microalgae strain, light supply, $\mathrm{pH}$ and nutrients availability (Cheah et al., 2018).

Light intensity plays a crucial role in microalgal growth and lipid production. When growth conditions are optimal, the whole amount of light energy captivated 
by pigments is transformed into ATP or NADPH which is ultimately stored as starch or lipids (Mondal et al., 2017). The effect of light may be observed in current study when A. gracilis was cultured in $60 \mu_{\text {molm }}^{-2} \mathrm{~s}^{-1}$ lipid levels were less than $3.2 \% \mathrm{DW}$ in NPK culture medium. The same microalga was cultured under the same conditions, but lipids levels were $11.5 \%$, in $40 \mu \mathrm{molm}^{-2} \mathrm{~s}^{-1}$ light intensity (Sipaúba-Tavares et al., 2017).

According to (Kim et al., 2013) high growth rate of microalgae and $\mathrm{N}$ and $\mathrm{P}$ absorption capacity occur within a broad $\mathrm{pH}$ range (between 5 and 9). High absorption amounts of TIN and TP in H. pluvialis culture and $A$. gracilis culture in $\mathrm{CHU}_{12}$ culture medium were associated with $\mathrm{pH} 7$ and 9, respectively.

The proportion of protein and lipids are hardly changed by cultivation modes, such as autotrophic, heterotrophic and mixotrophic cultivations unless there are stress conditions, an intrinsic physiological property of microalgae (Li et al., 2019). The use of mixotrophic conditions for in vitro cultivation of microalgae should be implemented. In fact, cell growth in mixotrophic conditions is not strictly dependent on photosynthesis. In other words, the use of light energy to activate the photosynthesis process may be reduced, with a decrease in production costs and increase in lipid levels. One may underscore that microalgae behave differently and respond to culture conditions according to their intrinsic factors. Consequently, the use of sugarcane molasses showed different results for the two microalgae and did not interfere in the physical and chemical conditions of culture media. The use of sugarcane molasses is an alternative as a carbon source, especially in the case of $H$. pluvialis, since the growth of microalga $A$. gracilis with the use of this industrial byproduct was affected mainly in the NPK medium.

\section{Acknowledgements}

The authors would like to thank FAPESP for funding (14/24697-3) and for the scholarship grant to the second author (2017/11001-9). Thanks are also due to CNPq for the scholarship award to the first author (PQ 305343/2014-9).

\section{References}

ASSOCIATION OF OFFICIAL ANALYTICAL CHEMISTS AOAC, 1990. Official methods of analysis. 15th ed. Washington: AOAC, $771 \mathrm{p}$.

CHEAH, W.Y., SHOW, P.L., JUAN, J.C., CHANG, J.S. and LING, T.C., 2018. Enhancing biomass and lipid productions of microalgae in palm oil mill effluent using carbon and nutrient supplementation. Energy Conversion and Management, vol. 164, pp. 188-197. http://dx.doi.org/10.1016/j.enconman.2018.02.094.

CHU, S.P., 1942. The influence of mineral composition on the medium in the growth of planktonic alga. Journal of Ecology, vol. 30, no. 2, pp. 284-325. http://dx.doi.org/10.2307/2256574.

GAURAV, K., SRIVASTAVA, R., SHARMA, J.G., SINGH, R. and SINGH, V., 2016. Molasses-based growth and lipid production by Chlorella pyrenoidosa: a potential feedstock for biodiesel. International Journal of Green Ebergy, vol. 13, no. 3, pp. 320-327. http://dx.doi.org/10.1080/15435075.2014.966268.

GOLTERMAN, H.L., CLYMO, R.S. and OHMSTAD, M.A.M., 1978. Methods for physical and chemical analysis of fresh water. 2. ed. Oxford: Blackwell Scientific Publications, 213 p. IBP Handbook, no. 8.

GUILLARD, R.R.L. and LORENZEN, C.J., 1972. Yellow-green algae with chlorophyllide. Journal of Phycology, vol. 8, no. 1, pp. 10-14. https://doi.org/10.1111/j.1529-8817.1972.tb03995.x.

GUILLARD, R.R.L., 1973. Division rates. In: J.R. STEIN. Handbook of phycological methods. Culture methods and Growth Measurements. London: Cambridge University Press, p. 289-311.

HILLEBRAND, H., DÜRSELEN, C.D., KIRSCHTEL, D., POLLINGHER, U. and ZOHARY, T., 1999. Biovolume calculation for pelagic and benthic microalgae. Journal of Phycology, vol. 35, no. 2, pp. 403-424. http://dx.doi.org/10.1046/j.15298817.1999.3520403.x.

KIM, S., PARK, J.E., CHO, Y.B. and HWANG, S., 2013. Growth rate, organic carbon and nutrient removal rates of Chlorella sorokiniana in autotrophic, heterotrophic and mixotrophic conditions. Bioresource Technology, vol. 144, pp. 8-13. http:// dx.doi.org/10.1016/j.biortech.2013.06.068. PMid:23850820.

KOROLEFF, F., 1976. Determination of nutrients. In: E. GRASHOF and E. KREMLING, eds. Methods of seawater analysis. German: Verlag Chemie Wenhein, pp. 126-133.

LI, X., LI, W., ZHAI, J., WEI, H. and WANG, Q., 2019. Effect of ammonium nitrogen on microalgal growth, biochemical composition and photosynthetic performance in mixotrophic cultivation. Bioresource Technology, vol. 273, pp. 368-376. http:// dx.doi.org/10.1016/j.biortech.2018.11.042. PMid:30453251.

MADEIRA, M.S., CARDOSO, C., LOPES, P.A., COELHO, D., AFONSO, C., BANDARRA, N.M. and PRATES, J.A.M., 2017. Microalgae as feed ingredients for livestock production and meat quality: A Review. Livestock Science, vol. 205, pp. 111-121. http://dx.doi.org/10.1016/j.livsci.2017.09.020.

MONDAL, M., GHOSH, A., OINAM, G., TIWARI, O.N., GAYEN, K., DAS, P., MANDAL, M.K. and HALDER, G., 2017. Influence of carbon source and light intensity on biomass and lipid production of Chlorella sorokiana BTA 9031 isolated from coalfield under various nutritional modes. Energy Conversion and Management, vol. 145, pp. 247-254. http://dx.doi.org/10.1016/j. enconman.2017.05.001.

NUSCH, E.A., 1980. Comparison of different methods for chorophyll and phaeopigments determination. Archiv für Hydrobiologie, vol. 14, pp. 4-36. http://dx.doi.org/10.1127/0003-9136.

PIASECKA, A., KRZEMINSKA, I. and TYS, J., 2017. Enrichment of Parachlorella kessleri biomass with bio-products: oil and protein by utilization of beet molasses. Journal of Applied Phycology, vol. 29, no. 4, pp. 1735-1743. http://dx.doi.org/10.1007/ s10811-017-1081-y. PMid:28775655.

ROCHA, O. and DUNCAN, A., 1985. The relationship between cell carbon and cell volume in freshwater algae species used in zooplankton studies. Journal of Plankton Research, vol. 7, no. 2, pp. 279-294. http://dx.doi.org/10.1093/plankt/7.2.279.

SATHAZIVAM, R., RADHAKRISHNAN, R., HASHEM, A. and ABD-ALLAH, E.F., 2018. Microalgae metabolites: a rich source for food and medicine. Saudi Journal of Biological Sciences, vol. 26, no. 4, pp. 709-722. https://doi.org/10.1016/j. sjbs.2017.11.003. 
SCARDOELLI-TRUZZI, B. and SIPAÚBA-TAVARES, L.H., 2017. Sources of inorganic fertilizer in the growth of Haematococcus pluvialis Flotow (Chlorophyceae). Journal of Algal Biomass Utilization, vol. 8, no. 2, pp. 1-10.

SIPAÚBA-TAVARES, L.H. and ROCHA, O., 1993. Largescale cultivation of plankton for feeding larvae and fish fry: I-Algae green. Biotemas, vol. 6, no. 1, pp. 93-106. http://dx.doi. org/10.5007/2175-7925.

SIPAÚBA-TAVARES, L.H., IBARRA, L.C. and FIORESI, T.B., 2009. Ankistrodesmus gracilis (Reinsch) Korshikov (Chlorophyta) laboratory cultured in $\mathrm{CHU}_{12}$ and macrophyte with NPK media. Boletim do Instituto de Pesca, vol. 35, no. 1, pp. 111-118. http:// dx.doi.org/10.20950/1678-2305.

SIPAÚBA-TAVARES, L.H., SEGALI, A.M.D.L., BERCHIELLIMORAIS, F.A. and SCARDOELI-TRUZZI, B., 2017. Development of low-cost culture media for Ankistrodesmus gracilis based on inorganic fertilizer and macrophyte. Acta Limnologica Brasiliensia, vol. 29, pp. e5. http://dx.doi.org/10.1590/s2179-975x3916.

STATSOFT Inc., 2007. Statistica: data analysis software system. Version 8. Tulsa: Statsoft, Inc.

WANG, H., ZHOU, W., SHAO, H. and LIU, T., 2017. A comparative analysis of biomass and lipid content in five Tribonema sp. strains at autotrophic, heterotrophic and mixotrophic cultivation. Algal Research, vol. 24, Part A, pp. 284-289. http://dx.doi.org/10.1016/j. algal.2017.04.020.

WANG, S.K., WANG, X., TAO, H.H., SUN, X.S. and TIAN, Y.T., 2018. Heterotrophic culture of Chlorella pyrenoidosa using sucrose as the sole carbon source by co-culture with immobilized yeast. Bioresource Technology, vol. 249, pp. 425-430. http:// dx.doi.org/10.1016/j.biortech.2017.10.049. 